\title{
Locus of control in situations of successes and failures and personality traits in young athletes practicing team sports
}

\begin{abstract}
BACKGROUND
The aim of this study was to analyze locus of control in situations of successes and failures and personality traits in young people attending sport and non-sport classes. Based on a review of studies, it was presumed that young people who practice team sports have a higher internal locus of control, higher openness to experience, higher conscientiousness, and higher emotional stability than their peers who do not practice sport.
\end{abstract}

\section{PARTICIPANTS AND PROCEDURE}

Young people who took part in the study were both those who attended schools with sport education programs and those who attended non-sport schools. 63 students of the sixth grade of primary school and the first grade of junior high school were surveyed $(M=12.60)$. Two groups were distinguished: students who followed an extended sports curriculum practicing football and basketball $(n=31)$, and those who followed a standard curriculum $(n=32)$. The Questionnaire for Locus of Control and the Picture Based Personality Survey for Children, based on the Big Five model, were used in the analyses.
RESULTS

The results of the studies partially confirmed the assumed hypotheses and showed connections between locus of control in situations of failure and openness to experience in the group of athletes.

\section{CONCLUSIONS}

This study constitutes a summary of the first stage of a three-year longitudinal project. Conclusions from the study will allow characterization of developmental changes of locus of control and personality traits in young athletes. Assessment of personality profile constitutes help for sport psychology practitioners in preparing training that uses accurate reinforcement systems corresponding with the traits of players that are members of a team.

\section{KEY WORDS}

sport psychology; locus of control; personality traits; Big Five

Organization - 1: Institute of Psychology, Maria Curie-Skłodowska University, Lublin, Poland · 2: Department

of Psychology, Jan Kochanowski University, Kielce, Poland

aUthors' Contributions - A: Study design - B: Data collection - C: Statistical analysis - D: Data interpretation .

E: Manuscript preparation · F: Literature search · G: Funds collection

Corresponding Author - Sara Filipiak, Ph.D., Institute of Psychology, Maria Curie-Skłodowska University,

5 Plac Litewski, 20-080 Lublin, Poland, e-mail: s.filipiak@poczta.umcs.lublin.pl

TO CITE THIS ARTICLE - Filipiak, S., \& Łubianka, B. (2020). Locus of control in situations of successes and failures

and personality traits in young athletes practicing team sports. Health Psychology Report, 8(1), 47-58.

https://doi.org/10.5114/hpr.2019.90917

RECEIVED 20.09.2019 • REVIEWED 08.11.2019 • ACCEPTED 19.11.2019 • PUBLISHED 16.12.2019 


\section{BACKGROUND}

In modern society, sports activity understood as practicing various sport disciplines, both at amateur and professional level, connects the worlds of children, adolescents and adults (Stepulak, 2014). Various functions of sport correspond with educational goals that are being set in didactic, educational and prophylactic programs at schools (Czechowski, 2015). Sport and education are connected with each other in terms of improving the organism's adaptive skills, including the shaping of perseverance, self-discipline, coping with failures and supporting self-esteem and positive mood (Ferron, Narring, Cauderay, \& Michaud, 1999; Field, Diego, \& Sanders, 2001; Sozański, 2003; Bowker, 2006; Wiese-Bjornstal, LaVoi, \& Omli, 2009).

In sport psychology, the analysis of personality traits in athletes is an area of huge interest. However, there is a lack of studies on connections between locus of control and personality traits in young people at an earlier stage of preparations for professional sports activity - called directed (Regulation of the Minister of National Education in Poland, October 15, 2012). Therefore, the aim of this study is to fulfill this gap in the literature. As studies show, personality traits are connected with the athlete's behavior in a situation of changing team's sport result. They also influence the preference for specific strategies of coping with failures. Personality traits are especially responsible for the way of interpreting one's failures, analysis of their reasons in order to avoid making the same or similar mistakes in the future, and motivating oneself to further work after experiencing defeat (SkorupskiCymbaluk, 2018; Tokarz \& Salwin, 2018). Sports abilities are the result of adequate physical preparation, as well as mental preparation connected with readiness for persistent work during training and coping with failures (Brewer, 2009; Gould, Flett, \& Bean, 2009; Ilyasi \& Salehian, 2011; Velkić, Knežewić, \& Rodić, 2014; Appaso \& Ramchandra, 2018). Based on determining the personality profile of an athlete, the level of their future achievements might be predicted. Analysis of personality traits gives the possibility of planning work with athletes of various sport disciplines, directed at strengthening self-esteem, self-discipline, resistance to criticism and ongoing self-motivation for further work (Kaiseler, Polman, \& Nicholls, 2012; Lopez \& Santelices, 2011; Roberts \& Woodman, 2017).

The concept of locus of control derives from social learning theory by Julian B. Rotter (1966). This construct refers to the generalized conviction of an individual regarding his ability to control the events that he takes part in. These beliefs are described in the categories of influence or dependence. It forms a continuum from an internal to an external locus of control. Control of reinforcement location is an individual trait. The belief that the results of one's actions are in line with one's behaviors, abilities or traits is called an internal locus of control, whereas the belief that the ultimate result of one's efforts is not in line with one's action and is interpreted as a consequence of coincidence, luck or bad luck is called an external locus of control (Drwal, 1995).

Theoretical works and results of empirical studies regarding locus of control allow for providing a description of functioning of people that differs in terms of locus of control (see Łukaszewski, 1984; Drwal, 1995; Kulas, 1998; Poznaniak, 1998). People with a shift towards an internal locus of control prefer to decide on their own about their behavior. They believe that what happened, what is happening at the moment and what might happen are directly connected with what they did, what they are doing or what they are about to do. An individual with an internal locus of control believes in their abilities to influence the course of action, sets a higher level of aspiration and considers the possibility of success higher. They independently make decisions and assume responsibility for them. In case of failure they seek the fault in themselves and not in their surroundings. In case of success, they attribute most credit to themselves and might present themselves in an excessively positive way (Poznaniak, 1998). Individuals with an external locus of control are dependent on their surroundings, they are directed by other people (family, school, mass media), as well as present orders, bans and instructions. Such individuals are convinced that the results of their own actions are determined by external situation, coincidence, other people, are independent of their behavior. Individuals with an external locus of control explain their successes by luck or good fortune and they explain failure with an unfavorable set of external factors. Such individuals are more subject to norms and external circumstances and to a lesser degree make independent decisions. It is nevertheless worth noting that an external locus of control does not have to constitute a simple negation of an internal locus of control (Gliszczyńska, 1990), as the locus of control might depend on the particular sphere of life.

Locus of control is a result of a developmental process. With age and gaining cognitive competence in differentiating events that are in a cause-and-result relation with an individual's actions from those that are not, there is a transition from an external locus of control, characteristic of the period of childhood, to an internal locus of control, which usually increases in the period of adolescence. Developmental changes of locus of control are also connected with the influence of family and school environment and individual experiences (Krasowicz-Kupis \& Kurzyp-Wojniarska, 1990; Kulas, 1998). The concept of internal or external control is not a rigid typology which enables people to be arbitrarily categorized. It is used in order to explain differences among people in thinking about one's abilities to influence their surroundings. Locus 
of control helps to explain and predict an individual's behavior in various situations, starting from problem solving, learning, setting the level of aspiration, social activeness, to reacting in situations of losing health or physical well-being. Despite the fact that locus of control derives from social learning theory by Rotter, it substantially exceeds its basic assumptions (Drwal, 1995). This means that it is worth attempting to test its usefulness in other theoretical contexts and fields of practical implementation of psychological knowledge in sport, where achieved successes and failures are integral parts of professional life.

Modern sport psychology stresses the questions connected with early diagnosis and support of children and young people who are active in sports as a possibility to shape their various mental processes in the direction of supporting their level of achievements (Blecharz, 2006; Rutkowska, Bergier, \& Witkowski, 2014; Siekańska, 2015). Sport achievement as a result of sports activity might be interpreted by an athlete in the context of locus of control in two ways. In the first case, sports achievements might be interpreted as dependent on individual work, actual abilities, skills or personality traits of a given athlete, which is more characteristic of athletes with an internal locus of control. On the other hand, the result of sports activity might be understood as the effect of a trainer's work, audience's support, coincidence - in the case of athletes with an external locus of control (Rychta, 1992; Kulas, 2003). The authors of the studies also point out the dependence of locus of control in athletes on the type of practiced sport discipline - individual or team (Kishore, 2016), way of assessing the score - arbitrary or connected with referee's subjective opinion (Kosmidou, Giannitsopoulou, \& Proios, 2015) and the level of ability in sports activity - amateur or professional (Szablowski, 2004; Chugh, Kale, \& Jha, 2012).

Young people who practice sport show more internal locus of control than their peers who do not practice sport (see Kościelak \& Maroszek, 1998; Szablowski, 2004). In addition, as indicated in the studies of Kulas (1994) and Chugh et al. (2012), locus of control is an important factor differentiating the level of sports achievements. The more advanced the level of sports activity presented by athletes is, the more internal their locus of control is. However, a hypothesis formulated a priori stating that sports training contributes to the shaping of internal locus of control is not always reflected in the results of studies (cf. Kulas, 2003; Kishore, 2016). Full conclusions in this aspect might be drawn from longitudinal studies, based on which a detailed reference to the development of locus of control in young athletes and factors that condition it might be made. Nevertheless, psychological analyses regarding locus of control in athletes based on the longitudinal study strategy are exceptions (cf. Kulas, 2003; Guszkowska, 2004), in both Polish and foreign research.
Studies of Kulas (2003) regarding the development of locus of control in young people practicing sport showed that there are significant changes in locus of control in late childhood and early adolescence. In a three-year research plan, the author noted that children who start practicing sport have significantly more internal locus of control when compared with their peers from non-sport classes. However, the entire longitudinal studies do not confirm the hypothesis of the positive influence of practicing sports on locus of control. Initially, differences which were present in 10- and 11-year-old children from sport classes manifested in internal locus of control, when compared with their peers from non-sport classes, diminished after second measurement and disappeared in the third stage of the studies. Kulas supposes that the increase of external locus of control in sport classes might have, apart from causes connected with school demands, such as the changes in organization of education (transition to grade IV in the old system of education), also causes connected with sport. Sport training does not immediately and does not always lead to expected results, despite long and exhausting practice. Maintained lack of connection between one's sports activity and its results might lead to a sense of helplessness and weakening of the belief in one's influence on the course of events.

Studies of Szablowski (2004) show locus of control in young basketball players in relation with their level of sports ability. Studies were carried out in two age and contest groups - cadets and juniors. Surveyed athletes showed undefined or shifted towards internal locus of control both in situations of their successes and experienced failures. What is more, in older and more experienced athletes, the internal locus of control prevailed.

Rutkowska et al. (2014) carried out research regarding styles of coping with stress and locus of control in situations typical for sport in girls aged 16-18 who trained in football. Studies indicated that female football players had more internal locus of control in situations of stress than in situations of failure. Internal locus of control was significantly higher in situations of training than in situations of competition or interpersonal relations. In addition, it was found that the style of coping with stress directed at avoidance and emotions dominated over the style directed at tasks.

In contemporary psychology, a recognized model describing personality in categories of traits is the Big Five model by Paul Costa and Robert McCrea (Costa \& McCrae, 1994; McCrae \& Costa, 2003). This model is supported by numerous empirical reports stemming from studies carried out all over the world. According to the authors, personality is responsible for the ways of thinking, feeling and behaving that are specific for a given individual. These traits are relatively permanent throughout one's life, biologically conditioned and universal in terms of culture.
Locus of control and personality traits in young athletes practicing team sports 
Sara Filipiak, Beata Łubianka
The model comprises five personality traits: extraversion, neuroticism, conscientiousness, agreeableness and openness to experience. The traits are internal dispositions, which shape the view of oneself and also one's belief in one's effectiveness (McCrae \& Costa, 2003; Terracciano, McCrae, Brant, \& Costa, 2005; Cieciuch, 2010).

Extraversion relates to the readiness to establish interpersonal contacts and take part in social situations. Individuals with high extraversion are talkative and seek contact with other people. On the other hand, low intensity of extraversion describes individuals who rather tend to avoid social relations. It is reported that there are more extroverts than introverts among athletes, which is connected with higher need for stimulation in order to attain the appropriate level of excitement (cf. Eysenck, 1982; Derbis \& Jędrek, 2010). Sports activity also secondarily supports an extrovert attitude through the necessity of an athlete to take part in various social situations during training or public performances. It is also reported that extraversion is higher in the case of athletes practicing team sports than those practicing individual disciplines (Derbis \& Jędrek, 2010).

Neuroticism relates to the traits connected with emotional stability level. Individuals with high intensity of this trait more often feel anxiety, are worse when it comes to coping with stress, tend to be impulsive and unpredictable in their reactions. Emotionally stable individuals are calm, balanced and predictable in their emotional reactions. They adapt to new situations and cope with difficult situations better. Derbis and Jędrek (2010) note that among athletes, neuroticism is at a moderate level. The authors state that neuroticism is a trait differentiating athletes practicing individual sports from those practicing team sports. Team sports, in which physical effort and mental resources are shared among individual team members, are probably practiced by more people with higher intensity of neuroticism. Collective sports activity is safer in the psychological aspect as the experience of stress is divided among team members and constitutes less burden for an individual athlete. When practicing individual sport, a given person has to be mentally resilient to such an extent that they are able to cope with burdens of both physical and mental nature on their own. That is why such athletes are usually more emotionally stable.

Conscientiousness as the next dimension of personality is connected with the readiness to take up effort and steady work. It also relates to the ability to prioritize one's actions in terms of abilities to achieve important goals. Conscientious individuals are diligent and have a need for order. Low conscientiousness is connected with lower perseverance and patience during work. High conscientiousness and engagement in performed work support achievements and satisfaction that stems from them. It is es- pecially visible in team sports, in which, as per Derbis and Jędrek (2010), conscientiousness of each team member contributes to the work of the entire team.

The influence of the remaining two personality traits on sports activity is less straightforward. Agreeableness relates to the ability to cooperate and readiness to take part in group endeavors. Agreeable individuals avoid competition and conflict, and value good interpersonal relations over individual benefits. Low agreeableness is connected with a competitive attitude and the need for domination over other people. The last dimension of personality, openness to experience, relates to the readiness to seek changes and diversity in everyday life. Individuals with high openness to experience do not avoid changes, are curious in terms of new experiences. They are tolerant of ambivalence and ready to analyze complex motives of human behaviors. They are usually resourceful and have wide-ranging interests (Costa \& McCrae, 1994). Individuals with low openness to experience are more comfortable in situations that are secure and known; they are less willing to seek changes.

Studies concerning athletes' personality traits in the period of adolescence, including fear of failure, were carried out on people practicing football (Sagar, Busch, \& Jowett, 2010) and gymnastics (Lufi \& Tenenbaum, 1991). Perseverance is a trait which to a great extent is responsible for achieving high sport results and is connected with the need for intensive work before starting training at a very young age. Results of studies carried out on young athletes showed that boys had a higher level of perseverance when compared with their peers who did not train in this discipline (Lufi \& Tenenbaum, 1991). In Turkey, Shokoufeh and Erhan (2016) surveyed 180 young men aged from 16 to 28 . Young men surveyed were those who practiced various sport disciplines, including basketball and football, but also those who did not practice any sport at all. The results showed that people who practiced sports had higher intensity of extraversion. In Poland, studies on young wrestlers' personality were carried out by Botwina (2004), among others, 180 boys aged from 13 to 18 took part in the studies. The surveyed group comprised boys who were achieving successes in district competitions and those who were not. Among boys who achieved successes, the author noted moderate correlations between neuroticism and aggression. These athletes had high intensity of aggression, which was increasing with training. Daniluk and Litwiniuk (2004) surveyed 16 members of the Polish Olympic judo team aged 16-30. The results showed that the participants had medium intensity of neuroticism, and more than half of participants were extroverts. There were also moderate correlations between neuroticism and anxiety-state in the group surveyed. Guszkowska (2004) carried out twoyear longitudinal studies among 289 high school students aged from 14 to 15 , distinguished on the basis 
of lower and higher physical activity, including members of sport clubs actively practicing sport and those practicing sport as a form of recreation. The results showed that in both measurements, young people active in sports had higher extraversion, whereas in the first measurement they had lower agreeableness than their peers not active in sports. The author notes that lower agreeableness in athletes, and consequent higher competitive attitude, might on the one hand influence their readiness to engage in sports activity; it might also be its effect. Interestingly, these studies also showed that between the first and the second measurement, the intensity of openness to experience increased, but only in young people practicing sport as a form of recreation. Lipowski (2004) surveyed 216 female and male athletes aged 9-10 practicing gymnastics, acrobatics, swimming and triathlon, and also a comparison group of 115 children at the same age but not practicing sports. The results showed that people who actively practiced sports were more emotionally stable. The author explains this phenomenon by the fact that children who take up sport are those who are better at coping with failures and more emotionally stable. In addition, practicing sport probably makes young people resilient to stressful situations and also supports their mental resilience. The two groups did not differ in terms of extraversion.

Differences regarding locus of control and personality traits in young athletes and their peers who do not practice sport are revealed in the results of studies carried out in Poland (Rychta, 2004; Botwina, 2004; Guszkowska, 2004; Lipowski, 2004; Derbis \& Jędrek, 2010; Skorupski-Cymbaluk, 2018; Tokarz \& Salwin, 2018), as well as all around the world (Lufi \& Tenenbaum, 1991; Sagar et al., 2010; Shokoufeh \& Erhan, 2016). Studies on personality have diagnostic significance for predicting a tendency to practice sport in a risky way, including extreme sports (Monasterio et al., 2016). In accordance with the results of this study, practicing sports in a risky way was connected with higher extraversion, openness to experience and emotional stability. Subsequent research showed that practicing sports in a risky way was connected with a tendency to seek sensations and additional stimulation, which was confirmed by higher results in the scale of openness to experience (Zuckerman, Kuhlman, Joireman, Teta, \& Kraft, 1993; Aluja, Garcia, \& Garcia, 2002; Roberti, 2004; Tok, 2011).

\section{THE PRESENT STUDY}

The review of existing studies on locus of control in social learning theory by Rotter (1966) and personality traits measured in the Big Five model by Costa and McCrae (1994) in young people practicing team sports allowed for formulation of the following research questions.
1. What are the differences in personality traits configuration among students of sport classes practicing team disciplines and students of non sport classes?

2. What are the differences in locus of control in situations of successes and failures in surveyed groups of students?

3. What is the connection between personality traits and locus of control in situations of successes and failures in students of sport classes and non-sport classes?

In order to obtain answers to the research questions, two first hypotheses were formulated based on subject literature regarding sport psychology. The third hypothesis has an exploratory character and fills in the gap in studies on connections among locus of control and personality traits in young athletes.

H1. Students of sport classes who train in team sports have a higher level of extraversion, neuroticism and conscientiousness than their peers from non-sport classes.

H2. Students of sport classes present a shift towards an internal locus of control in situations of both successes and failures.

H3. There is a connection of conscientiousness and openness to experience with locus of control in situations of successes and failures.

\section{PARTICIPANTS AND PROCEDURE}

\section{PARTICIPANTS}

Sixty-three students of the sixth grade of primary school and the first grade of junior high school were surveyed. 29 girls (46\%) and 34 boys (54\%) aged 12-13 $(M=12.60, S D=0.50)$ took part in the study. Two groups were distinguished among surveyed students. Group of students from sport classes comprised 31 persons (including 35\% girls). These were young people practicing team sports - football and basketball. The comparison group comprised 32 students (including $56 \%$ girls) from non-sport classes. Studies were carried out in Poland, in Lublin, in 3 schools in the school year $2016 / 2017$. Sport classes were arbitrarily chosen from schools in which, in accordance with the Regulation of the Minister of National Education of Poland (Regulation of the Minister of National Education of 15 October 2012), sport units (sport classes) are formed, and the first stage of sport training (called directed) is carried out. Students of these classes are athletes towards whom, in accordance with the principles of directed sport education, actions aimed at revealing their predispositions and talents qualifying them for training in a given sports discipline are being undertaken. Nonsport classes were arbitrarily chosen among schools that do not have sport units.

The authors of this article carried out studies in compliance with principles concerning confiden-
Locus of control and personality traits in young athletes practicing team sports 
Sara Filipiak, Beata Łubianka tiality, anonymity and voluntariness of taking part in studies. Studies were carried out with schools' principals' consent and in agreement with a school psychologist or pedagogue, after obtaining students' parents' written permission. The studies were carried out during one meeting with each class. Students were informed of the scientific aim of the study and of the fact that taking part is voluntary. Students of each class received feedback through their teachers after the studies were completed. This feedback was in the form of a collective description of characteristics of their personality traits and locus of control.

\section{MEASURES}

Questionnaire for Locus of Control. Locus of control was surveyed with the Questionnaire for Locus of Control by Krasowicz-Kupis and Kurzyp-Wojnarska (1990). When the study was conducted, in the school year $2016 / 2017$, it was an up-to-date version of this tool. This test is used to measure locus of control regarding consequences of one's behavior, a construct described in social learning theory by Rotter. The test comprises 46 questions, of which 36 have diagnostic value for locus of control. Half of the diagnostic questions refer to situations of success, and the other half refer to situations of failures. The sum of questions concerns generalized locus of control. The tool has satisfactory psychometric properties. The test was normalized to young people between 13 and 17 years of age.

Picture Based Personality Survey for Children. The study of personality traits in the Big Five model was carried out with the Picture Based Personality Survey for Children (PBPS-C v1) by Maćkiewicz and Cieciuch $(2012,2016)$. This tool is suitable for surveying children in late childhood and young adolescents. The pictorial character of this test takes into account cognitive abilities of young people, in whom, according to Piaget's theory (1974), there takes place the process of thinking development implying the transition of concrete reasoning to abstract reasoning. PBPS-C has its foreign equivalents used, among others, in Italy (Barbaranelli, Caprara, Rabasca, \& Pastorelli, 2003), Spain (Del Barrio, Carrasco, \& Holgado, 2006), Greece (Kokkinos \& Markos, 2015), Germany (Bleidorn \& Ostendorf, 2009) and France (Olivier \& Herve, 2015). A description of the Polish version can be found in the works of Cieciuch (2010), Maćkiewicz and Cieciuch (2012) and Cieciuch, Toczyłowska-Niemiec, and Barbaranelli (2016). Validation of the PBPS-C carried out by the authors using confirmatory factor analysis (CFA) and a quality indicator by Saris and Gallhofer, defined as the product of validity and reliability, are at a satisfactory level, which allows the tool to be considered good enough to be used in scientific research on personality traits in children and young people in the Big Five model (Maćkiewicz \& Cieciuch, 2012).
PBPS-C v1 is composed of 15 items. Each relates to a given personality dimension in the Big Five model. Each of them contains two pictures. Above each pair of pictures there is a short description of a given situation. The person surveyed reads the sentence and then chooses one of the pictures with the following instruction: "Think about how you most often behave in this kind of situation". The answer is given on a 5-level scale. The minimal score that a surveyed individual can obtain on each scale is 3 points, the maximal 15. There are two versions of PBPS-C v1: for younger children at grade I-III of primary school and for older children at grade IV-VI of primary school. In this study, the version for older children was used. It was decided that the NEO-FFI questionnaire would not be used in the study. This questionnaire is normalized to young people aged from 15; it is based on written description of personality traits (Zawadzki, Strelau, Szczepaniak, \& Śliwińska, 1998). It was presumed that for some surveyed, answering abstract questions describing individual personality traits might be difficult. The picture-based form of PBPS-C v1 might be used in order to measure personality traits in people entering the period of adolescence, in which there is an ongoing process of abstract thinking development.

\section{RESULTS}

Quantitative interpretation of obtained data was carried out based on the raw score from each research tool. Analyses of results are presented in the same order as research questions are. Presented results obtained by students practicing team sports and also students from non-sport classes refer to locus of control in situations of successes and failures, and their personality traits. In order to verify whether there are statistically significant differences among obtained results regarding personality traits and locus of control among students, the independent sample Student's $t$-test was used. Analyses of obtained data were carried out with the statistical package SPSS, version 24.

The order of tables presented below corresponds with the order of formulated questions. Analysis of the tables' contents allows for verification of hypotheses.

Data presented in Table 1 reveal significant differences in the four dimensions of personality between students from sport classes and from non-sport classes. These dimensions are as follows: extraversion, neuroticism, openness to experience and agreeableness. Young athletes are more extrovert and emotionally stable than their peers from non-sport classes whereas students from non-sport classes are more open to experience and agreeable.

Presented results in Table 2 show that students from sport classes have more internal locus of con- 
trol, in situations of both successes and failures, when compared with their peers from non-sport classes.

Data presented in Table 3 show a moderate correlation between openness to new experience and locus of control in situations of failures in students from sport classes. In non-sport classes, significant connections between personality traits and locus of control were not noted.

Table 1

Values of Student's t-test for results regarding personality traits obtained by the students of sport and non-sport classes

\begin{tabular}{|c|c|c|c|c|c|c|}
\hline \multirow[t]{3}{*}{ Personality traits } & \multicolumn{4}{|c|}{ Class } & \multirow[t]{3}{*}{$t$} & \multirow[t]{3}{*}{$p$} \\
\hline & \multicolumn{2}{|c|}{ sport } & \multicolumn{2}{|c|}{ non-sport } & & \\
\hline & $M$ & $S D$ & $M$ & $S D$ & & \\
\hline Extraversion & 12.31 & 1.82 & 10.13 & 2.50 & 3.97 & .001 \\
\hline Neuroticism & 7.72 & 3.10 & 9.58 & 1.98 & -2.82 & .001 \\
\hline Openness to experience & 9.25 & 2.78 & 10.03 & 2.00 & -1.27 & .020 \\
\hline Conscientiousness & 9.47 & 2.31 & 9.74 & 1.99 & -0.50 & .610 \\
\hline Agreeableness & 9.59 & 3.01 & 11.61 & 2.40 & -2.93 & .001 \\
\hline
\end{tabular}

Locus of control and personality traits in young athletes practicing team sports

Table 2

Values of Student's t-test for results regarding locus of control obtained by the students of sport and non-sport classes

\begin{tabular}{|c|c|c|c|c|c|c|}
\hline \multirow[t]{3}{*}{ Locus of control } & \multicolumn{4}{|c|}{ Class } & \multirow[t]{3}{*}{$t$} & \multirow[t]{3}{*}{$p$} \\
\hline & \multicolumn{2}{|c|}{ sport } & \multicolumn{2}{|c|}{ non-sport } & & \\
\hline & $M$ & $S D$ & $M$ & $S D$ & & \\
\hline Success situations & 11.97 & 2.81 & 10.03 & 3.15 & 2.57 & .010 \\
\hline Failure situations & 12.78 & 3.40 & 9.68 & 3.01 & 3.82 & .001 \\
\hline
\end{tabular}

Table 3

Values of Pearson's correlation coefficient $r$ for connections among personality traits and locus of control in situations of success, failure, and generalized control in the group of athletes

\begin{tabular}{lccc}
\hline Athletes & & \multicolumn{2}{c}{ Locus of control } \\
\hline Personality traits & Success situations & Failure situations \\
\hline Extraversion & $p$ & -.11 & .12 \\
& Pearson's $r$ & .538 & .511 \\
Neuroticism & $p$ & -.22 & .17 \\
& Pearson's $r$ & .221 & .335 \\
Openness to experience & $p$ & .27 & .37 \\
& Pearson's $r$ & .118 & .030 \\
Conscientiousness & $p$ & .02 & .06 \\
Agreeableness & $p$ & .879 & .713 \\
& Pearson's $r$ & -.29 & -.01 \\
\hline
\end{tabular}




\section{DISCUSSION}

The aim of this study was to analyze mutual connections among locus of control and personality traits in children who followed an extended sports curriculum at school. This study was carried out facing the need for sport psychology knowledge, which might be directed not only at the top athletes but also athletes at lower stage of sports ability (cf. Rychta, 2004). Studies showed that students from sport classes who trained in team sports had higher intensity of traits connected with readiness to seek and maintain interpersonal relations, being in the company of others, and seeking their advice and support when experiencing troubles. Young athletes practicing team sports also show lower agreeableness; therefore, they are more oriented towards rivalry and ready to compete, when compared with students from non-sport class. In situations in which they should show their advantage regarding their team's goal or their self-esteem is threatened, they are prone to rivalry behaviors. Low agreeableness among students practicing sport disciplines requiring cooperation is an area of future rearing influence that should promote cooperation in order to achieve goals of a team. They also have higher emotional stability and are more balanced than their colleagues from non-sport class. Moreover, the locus of control of young people attending sport classes in situations of successes and failures is shifted towards internal. These students also have lower, when compared with students from a non-sport class, readiness to seek changes. Result obtained in this study which show higher emotional stability in athletes and their lower openness to experience might mean that they feel confident and safe in situations that are known to them and predictable. Perhaps the necessity for selfdiscipline and for concentrating on achieving goals makes the surveyed group of young athletes focus on what can be achieved with the use of known and predictable strategies.

The obtained result refers to the results of longitudinal studies by Guszkowska (2004), who noted an increase in openness to experience, but only in young people practicing sports as a form of recreation. Conducted studies showed that in the group of athletes, there were connections between openness to experience and locus of control of failures. This means that along with an increase in readiness to engage in seeking the new and changes, their internal locus of control regarding situations of failures increases. This can be treated as an important signal regarding young athletes' potential for readiness to benefit from psychological influences. The fact of participating in sports activity, although it is the basis, is not a sufficient warrant of sport success. Creating accurate conditions promoting the sport form, including conscious and purposeful actions of people supporting athletes' mental preparation, is equally important (Siekańska \& Blecharz, 2018). That is why it is worthwhile to undertake actions towards shaping a task-based style of coping with stress, positive re-formulation of failures, or work with one's beliefs about oneself, one's successes and failures. Young athletes have a locus of control shifted more towards an internal locus of control in situations of successes and failures, which is consistent with results of studies carried out to date, which confirm the fact that practicing sport coexists with the sense of personal responsibility over events which occur in sport and everyday contexts. Individuals with an internal locus of control prefer taking up actions that would maximize the relationship between results and personal influence on them (Drwal, 1995). Rutkowska et al. (2014) point out the need for modification of the rules of conducting training so that it better fulfills athletes' needs. They postulate psychological support from trainers, which should aim at strengthening the internal locus of control, and also learning effective ways of coping with stress. Kulas (2003) highlights the fact that this is especially important in the case of young athletes, when sports achievements might not increase at the pace set by young people. The trainer or physical education teacher is a particularly important person in such situations as his praise and rewards, despite momentary failures, helps to release positive experiences and engagement. Such an influence constitutes an important motivational factor.

The results showed that in the group of athletes, increase in openness to changes and new experiences is connected with increase in internal control. It is an important conclusion for work with young athletes. Their achievements are on one hand the results of ongoing training and learnt schemata of reacting, for example, when their motivation for further effort drops. On the other hand, encouraging young athletes to try to experiment with new ways of acting might be for them a source of discovering their unknown resources. This process should however take place in controlled conditions, with the support of experienced preceptors, trainers or instructors.

Modern sport is inseparably connected with the influence of psychological training. Their aim is to increase athletes' effectiveness in order to obtain the best results. The role of those who support - trainers or members of the family - is important not only at the level of professional sport, but also at the beginning of sports activity. The obtained results fill the gap in studies on identification of personality traits and locus of control in young athletes practicing team disciplines. Knowledge in this area might help in widening forms and methods of didactic work for physical education teachers, sport trainers and other specialists who share psychological knowledge with athletes. Due to the specific configuration of personality traits, people react differently to the same stimuli. For example, individuals with intensified 
traits connected with neuroticism, differently than extroverts, strongly react with fear of punishment, which is why their actions are directed at its avoidance (Skorupski-Cymbaluk, 2018). The main mechanism of acting in extroverts is the need for achievement and reward. This distinction is important from the point of view of sport psychology practice as it sets different ways of motivating an athlete to act. While the trainer's stressing of potential victory, understood as a reward, would be an appropriate stimulus for an extrovert athlete, it might not motivate an athlete with higher intensity of anxiety in the same way. Decreasing emotional tension during training sessions might help such an athlete in accurate interpretation of reasons behind various sports events that they experience. In addition, the results of this study might help in creating programs for work with athletes practicing team disciplines, in which the stressed elements would be those connected with team-building, including explanation regarding the importance of personality traits for obtained sport results, the influence of an individual on the entire team, and how individual athletes are mutually dependent on one another in a sport situation.

An advantage of this study is the planned longitudinal character. In the future, final conclusions might provide knowledge regarding how personality and locus of control are being shaped in young athletes, and transfer this knowledge to the area of training supporting creation of an effective team. In this way, the study is in line with popularization of psychological knowledge in improving preceptors' competence and shows the need to include professional psychological support for young athletes as early as at school.

\section{LIMITATIONS}

There are however some limitations of this study. The first is the relatively small group of students who have been surveyed. Moreover, young athletes practiced two different sport disciplines (football and basketball). Both football and basketball are team disciplines; however, due to the specific requirements and game's rules, they may differ in terms of individual input of a player and level of personal responsibility for the obtained result. Therefore, practicing a specific sport discipline may support development of a particular set of personality traits. In future research, it would be worthwhile to analyze personality profiles and locus of control in groups differing by sport discipline (both team and individual). It would also be interesting to compare the results obtained in this study by young footballers and basketballers who follow an extended sports curriculum at schools with students from e-sport classes who practice sport in virtual reality.

\section{References}

Aluja, A., Garcia O., \& Garcia, L. F. (2002). A comparative study of Zuckerman's three structural models for personality through the NEO-PI-R, ZKPQ-III-R, EPQ-RS and Goldberg's 50-bipolar adjectives. Personality and Individual Differences, 33, 713-726. https://doi.org/10.1016/s0191-8869(01)00186-6

Appaso, K. A., \& Ramchandra, J. S. (2018). Emotional intelligence and sportsman personality among college students. The International Journal of Indian Psychology, 6, 37-44.

Barbaranelli, C., Caprara, G. V., Rabasca, A., \& Pastorelli, C. (2003). A questionnaire for measuring the Big Five in late childhood. Personality and Individual Differences, 34, 645-664. https://doi.org/10.1016/ s0191-8869(02)00051-x

Blecharz, J. (2006). Psychologia we współczesnym sporcie - punkt wyjścia i możliwości rozwoju [Psychology in contemporary sport - foundations and futher possibilities of development]. Przeglad Psychologiczny, 49, 445-462.

Bleidorn, W., \& Ostendorf, F. (2009). Ein Big Five-inventar für kinder und jungendliche [A Big Five inventory for children and adolescents]. Diagnostica, 55, 160-173. https://doi.org/10.1026/0012-1924.55.3.160

Botwina, R. (2004). Osobowościowo-temperamentalne uwarunkowania sukcesu juniorów i seniorów w zapasach [Personal and temperamental underpinnings of success of junior and senior players in wrestling]. In M. Mikołajczyk (Ed.), Korelaty psychologiczne aktywności ruchowej i sukcesów w sporcie [Psychological correlates of physical activity and sport successes] (pp. 41-46). Warszawa: Polskie Towarzystwo Naukowe Kultury Fizycznej.

Bowker, A. (2006). The relationship between sports participation and self-esteem during early adolescence. Canadian Journal of Behavioral Science, 38, 214-229. https://doi.org/10.1037/cjbs2006009

Brewer, B. W. (2009). Introduction. In B. W. Brewer (Ed.), Handbook of sport medicine and science. Sport psychology (pp. 1-7). Oxford: Willy-Blackwell.

Chugh, G. D., Kale, R. K., \& Jha, P. C. (2012). Locus of control of cricket players, Sport - Science \& Practice, 2, 29-38.

Cieciuch, J. (2010). Pięcioczynnikowa struktura osobowości we wczesnej adolescencji [Five-structure of personality in early adolescence]. Studia Psychologica, 10, 251-271.

Cieciuch, J., Toczyłowska-Niemiec, K., \& Barbaranelli, C. (2016). Kwestionariuszowy pomiar pięciu cech osobowości dzieci i dorastających. Polska adaptacja Big Five Questionnaire-Children (BFQ-C) [Questionnaire measurement of five personality traits in children and adolescents. Polish adaptation of Big Five Questionnaire-Children (BFQ-C)]. Psychologia Rozwojowa, 21, 73-85. https://doi.org/ 10.4467/20843879PR.16.011.5089
Locus of control and personality traits in young athletes practicing team sports 
Costa, P. T. Jr, \& McCrae, R. R. (1994). Revised NEO Personality Inventory (NEO-PI-R) and NEO-Five Factor Inventory (NEO-FFI) Professional Manual. Odessa, FL: Psychological Assessment Resources.

Czechowski, J. (2015). Sport w perspektywie procesu wychowawczego [Sport in the perspective of education process]. Przeglad Pedagogiczny, 2, 161-178.

Daniluk, A., \& Litwiniuk, A. (2004). Wybrane cechy osobowości a poziom agresji u zawodników kadry olimpijskiej judo [Some personality traits and

Sara Filipiak, Beata Łubianka level of aggression among judo olimpic team players]. In M. Mikołajczyk (Ed.), Korelaty psychologiczne aktywności ruchowej i sukcesów w sporcie [Psychological correlates of physical activity and sport successes] (pp. 64-69). Warszawa: Polskie Towarzystwo Naukowe Kultury Fizycznej.

Del Barrio, V., Carrasco, M., \& Holgado, F. (2006). Factor structure invariance in the children's Big Five questionnaire. European Journal of Psychological Assessment, 22, 158-167. https://doi.org/10.1027/10155759.22.3.158

Derbis, R., \& Jędrek, K. (2010). Poczucie jakości życia a osobowość sportowców dyscyplin indywidualnych i zespołowych [Subjective quality of life and personality of team and individual sport disciplines' players]. Przegląd Psychologiczny, 53, 9-32.

Drwal, R. Ł. (1995). Poczucie kontroli jako wymiar osobowości - podstawy teoretyczne, techniki badawcze i wyniki badań [Locus of control as a dimension of personality - theoretical background, diagnostic methods and research]. In R. Ł. Drwal, P. Brzozowski, \& P. Oleś (Eds.), Adaptacja kwestionariuszy osobowości. Wybrane zagadnienia i techni$k i$ [Adaptation of personality questionnaires. Selected issues and techniques] (pp. 199-227). Warszawa: PWN.

Eysenck, H. J. (1982). Personality, genetics, and behavior: Selected papers. New York: Praeger.

Ferron, C., Narring, F., Cauderay, M., \& Michaud, P. (1999). Sport activity in adolescence: Associations with health perceptions and experimental behaviours. Health Education Research, 14, 225-233. https://doi.org/10.1093/her/14.2.225

Field, T., Diego, M., \& Sanders, C. E. (2001). Exercise is positively related to adolescent's relationships and academics. Adolescence, 36, 105-110.

Gliszczyńska, X. (1990). Konkretność i ogólność poczucia kontroli [Concrete and general sense of locus of control]. Przegląd Psychologiczny, 33, 597-611.

Gould, D., Flett, M. R., \& Bean, E. (2009). Mental preparation for training and competition. In B. W. Brewer (Ed.), Handbook of sport medicine and science. Sport psychology (pp. 53-63). Oxford: Willy-Blackwell.

Guszkowska, M. (2004). Czym różnią się młodzi sportowcy od aktywnych ruchowo rówieśników? [How young athletes differ from their peers active in sport?]. In M. Mikołajczyk (Ed.), Korelaty psychologiczne aktywności ruchowej i sukcesów w spor-

cie [Psychological correlates of physical activity and sport successes] (pp. 107-115). Warszawa: Polskie Towarzystwo Naukowe Kultury Fizycznej. Ilyasi, G., \& Salehian, M. H. (2011). Comparison of personality traits between individual and team athletes. Middle-East Journal of Scientific Research, 9, 527-530.

Kaiseler, M., Polman, R. C. J., \& Nicholls, A. R. (2012). Effects of the Big Five personality dimensions on appraisal coping, and cooping effectiveness in sport. European Journal of Sport Science, 12, 62-72. https://doi.org/10.1080/17461391.2010.551410

Kishore, V. (2016). Role of locus of control among different sports categories. International Journal of Physical Education, Sports and Health, 3, 373-374.

Kokkinos, C. M., \& Markos, A. (2015). The Big Five Questionnaire for Children (BFQ-C). Factorial invariance across sex and age in a Greek sample of preadolescents. European Journal of Psychological Assessment, 33, 1-5. https://doi.org/10.1027/10155759/a000273

Kosmidou, E., Giannitsopoulou, E., \& Proios, M. (2015). Perceived locus of control in rhythmic gymnastics by coaches and judges. Sport Science Review, 24, 89-102. https://doi.org/10.1515/ssr-2015-0010

Kościelak, R., \& Maroszek, K. (1998). Poczucie umiejscowienia kontroli i samoocena a wynik sportowy [Locus of control, self-esteem and sport achievements]. In T. Rychta (Ed.), Osobowość a zachowanie celowe sportowców [Personality and purposeful behavior of athletes] (pp. 145-156). Warszawa: Biblioteka Trenera.

Krasowicz-Kupis, G., \& Kurzyp-Wojnarska, A. (1990). Kwestionariusz do Badania Poczucia Kontroli (KBPK) [Questionnaire for Locus of Control]. Warszawa: Polskie Towarzystwo Psychologiczne.

Kulas, H. (1994). Poczucie kontroli jako czynnik warunkujący poziom osiągnięć sportowych żeglarzy [Locus of control as a factor determining sport achievements of sailors]. Sport Wyczynowy, 5-6, 80-85.

Kulas, H. (1998). Rozwój poczucia kontroli u dzieci w wieku szkolnym [Development of locus of control in school children]. Psychologia Wychowawcza, 3, 219-228.

Kulas, H. (2003). Uprawianie sportu a rozwój poczucia umiejscowienia kontroli u dzieci w wieku szkolnym [Engagement in sport and development of locus of control in school children]. In T. Rychta \& M. Guszkowska (Eds.), Wktad nauk humanistycznych do wiedzy o kulturze fizycznej. Tom 3: Psychologia sportu [Contribution of humanities to knowledge about physical culture. Volume 3: Sports psychology] (pp. 137-142). Warszawa: Polskie Towarzystwo Naukowe Kultury Fizycznej.

Lipowski, M. (2004). Neurotyzm i ekstrawersja jako moderatory sukcesu dzieci uprawiających sport wyczynowy [Neuroticism and extraversion as moderators of professional sport successes in children]. 
In M. Mikołajczyk (Ed.), Korelaty psychologiczne aktywności ruchowej i sukcesów w sporcie [Psychological correlates of physical activity and sport successes] (pp. 139-149). Warszawa: Polskie Towarzystwo Naukowe Kultury Fizycznej.

Lopez, A. V., \& Santelices, O. Y. S. (2011). Personality characteristics of elite table tennis athletes of the Philippines: basis for a proposed recruitment program. The $12^{\text {th }}$ ITTF Sports Science Congress, May 5-7, 2011, Rotterdam, The Netherlands.

Lufi, D., \& Tenenbaum, G. (1991). Persistence among young male gymnasts. Perceptual and Motor Skills, 72, 479-482. https://doi.org/10.2466/pms.72.2.479-482

Łukaszewski, W. (1984). Szanse rozwoju osobowości [Chances of personality development]. Warszawa: PWN.

Maćkiewicz, M., \& Cieciuch, J. (2012). Jak mierzyć cechy Wielkiej Piątki u dzieci? Prace nad Obrazkowym Pomiarem Cech Osobowości Dzieci (OPCO-D) [How to measure Big Five Traits in children? Works on Picture Based Personality Survey for Children]. Psychologia Rozwojowa, 17, 69-82.

Maćkiewicz, M., \& Cieciuch, J. (2016). Pictorial Personality Traits Questionnaire for Children (PPTQ-C) a new measure of children's personality traits. Frontiers in Psychology, 7, 1-11. https://doi.org/10.3389/ fpsyg.2016.00498

McCrae, R. R., \& Costa, P. T. (2003). Personality in adulthood: A five-factor theory perspective ( $2^{\text {nd }}$ ed.). New York: Guilford Press.

Monasterio, E., Mei-Dan, O., Hackney, A. C., Lane, A. R., Zwir, I., Rozsa, S., \& Clonninger, C. R. (2016). Stress reactivity and personality in extreme sports athletes: the psychobiology of BASE jumpers. Psychology \& Behavior, 167, 289-297. https://doi.org/10.1016/j. physbeh.2016.09.025

Olivier, M., \& Herve, M. (2015). The Big Five Questionnaire for Children (BFQ-C): a French validation on 8- to 14-year-old children. Personality and Individual Differences, 87, 55-58. https://doi.org/10.1016\%2Fj. paid.2015.07.030

Piaget, J. (1974). Understanding causality. New York: Norton.

Poznaniak, W. (1998). Teoria uczenia się społecznego jako model normalnego i zaburzonego funkcjonowania jednostek i grup [Social learning theory as a model of normal and abnormal functionning of people and groups]. In H. Sęk (Ed.), Spoteczna psychologia kliniczna [Social clinical psychology] (pp. 70-94). Warszawa: PWN.

Roberti, J. W. (2004). A review of behavioral and biological correlates of sensation seeking. Journal of Research in Personality, 38, 256-279. https://doi. org/10.1016/s0092-6566(03)00067-9

Roberts, R., \& Woodman, T. (2017). Personality and performance: moving beyond the Big Five. Current Opinion in Psychology, 16, 104-108. https:// doi.org/10.1016/j.copsyc.2017.03.033
Rotter, J. B. (1966). Generalized expectancies for internal versus external control of reinforcement. Psychological Monograph, 80, 1-28. https://doi. org/10.1037/h0092976

Rozporządzenie Ministra Edukacji Narodowej z dnia 15.10.2012 w sprawie warunków tworzenia, organizacji oraz działania oddziałów sportowych, szkół sportowych oraz szkół mistrzostwa sportowego [Regulation of the Minister of National Education on the conditions for the creation, organization and operation of sports departments, sports schools and sports championship schools, October 15, 2012]. Retrieved from http://prawo.sejm.gov.pl/isap.nsf/ download.xsp/WDU20120001129/O/D20121129.pdf

Rutkowska, K., Bergier, J., \& Witkowski, Z. (2014). Styles of coping with stress and locus of control in sporting situations in a group of young female football players. Human Movement, 15, 60-64. https://doi.org/10.2478/humo-2014-0004

Rychta, T. (1992). Cechy osobowościowe i ich funkcje regulacyjne [Regulatory functions of personality traits]. Trening, 1, 275-322.

Rychta, T. (2004). Osobowość i sport [Personality and sport]. In M. Mikołajczyk (Ed.), Korelaty psychologiczne aktywności ruchowej i sukcesów w sporcie [Psychological correlates of physical activity and sport successes] (pp. 13-28). Warszawa: Polskie Towarzystwo Naukowe Kultury Fizycznej.

Sagar, S. S., Busch, B. K., \& Jowett, S. (2010). Success and failure, fear of failure, and coping responses of adolescent academy football players. Journal of Applied Sport Psychology, 22, 213-230. https://doi. org/10.1080/1041

Shokoufeh, S., \& Erhan, S. E. (2016). Personality and aggression compared between sportsman and non-sportsmen in Erzurum province. International Journal of Sports Science, 6, 27-31.

Siekańska, M. (2015). Rola osób znaczących we wspieraniu rozwoju talentów sportowych [Role of authorities in supporting sport talents]. Psychologia Wychowawcza, 8, 153-169.

Siekańska, M., \& Blecharz, J. (2018). Dlaczego współczesny sport potrzebuje psychologii? [Why contemporary sport needs psychology?]. Przegląd Psychologiczny, 61, 11-23.

Skorupski-Cymbaluk, J. (2018). Czy neurotycy boją się skakać? Osobowościowe predyktory uprawiania sportu [Do neurotics fear jumping? Personality as a predictor of sport practising]. Ogrody Nauk i Sztuk, 8, 453-458.

Sozański, H. (2003). Współzawodnictwo sportowe dzieci i młodzieży w perspektywie europejskiej [Competitions of children and adolescents in European perspective]. In Z. Żukowska \& R. Żukowski (Eds.), Wychowanie poprzez sport [Education through sport] (pp. 42-61). Warszawa: Ministerstwo Edukacji Narodowej i Sportu oraz Polskie Towarzystwo Naukowe Kultury Fizycznej.
Locus of control and personality traits in young athletes practicing team sports 
Stepulak, M. Z. (2014). Psychologiczny wymiar wychowania poprzez sport [Psychological aspects of education through sport]. In P. Mazur (Ed.), Wychowanie poprzez sport. Wielość spojrzeń i doświadczeń [Education through sport. A multitude of perspectives and experiences] (pp. 29-43). Chełm: PWSZ.

Szablowski, K. (2004). Wpływ poczucia kontroli na poziom sportowy młodych koszykarzy [Influence of locus of control on sport achievements of young

Sara Filipiak, Beata Łubianka basketball players]. In M. Mikołajczyk (Ed.), Korelaty psychologiczne aktywności ruchowej i sukcesów w sporcie [Psychological correlates of physical activity and sport successes] (pp. 118-126). Warszawa: Polskie Towarzystwo Naukowe Kultury Fizycznej.

Terracciano, A., McCrae, R. R., Brant, L. J., \& Costa, P. T. Jr. (2005). Hierarchical linear modeling analyses of the NEO-PI-R scales in the Baltimore longitudinal study of aging. Psychology and Aging, 20, 493-506. https://doi.org/10.1037/0882-7974.20.3.493

Tok, S. (2011). The Big Five personality traits and risky sport participation. Social Behavior and Personality, 38, 1105-1112. https://doi.org/10.2224/ sbp.2011.39.8.1105

Tokarz, A., \& Salwin, E. (2018). Model przegranej w sporcie na przykładzie żeńskiej piłki siatkowej [Model of failure on the basis of female volleyball]. Przegląd Psychologiczny, 61, 61-76.

Velkić, D., Knežević, J., \& Rodić, N. (2014). Relations of some personality traits and characteristics of sportsmen with the level of sport anxiety. SportLogia, 10, 35-43. https://doi.org/10.5550/sgia.141001.en.005v

Wiese-Bjornstal, D. M., LaVoi, N. M., \& Omli, J. (2009). Child and adolescent development and sport participation. In B. W. Brewer (Ed.), Handbook of sport medicine and science. Sport psychology (pp. 97-112). Oxford: Willy-Blackwell.

Zawadzki, B., Strelau, J., Szczepaniak, P., \& Śliwińska, M. (1998). Inwentarz Osobowości Paula T. Costy Jr i Roberta R. McCrae. Adaptacja polska [Personality Inventory of P. T. Costa Jr and R. R. McCrae. Polish adaptation]. Warszawa: Pracownia Testów Psychologicznych Polskiego Towarzystwa Psychologicznego.

Zuckerman, M., Kuhlman, D. M., Joireman, J., Teta P., \& Kraft, M. (1993). A comparison of three structural models for personality: The Big Three, the Big Five, and the alternative Five. Journal of Personality and Social Psychology, 65, 757-768. https://doi. org/10.1037/0022-3514.65.4.757 